Article

\title{
Silenced Motherhood(s): Forbidden Motherings in the Early Childhood Classroom
}

\author{
Dana Frantz Bentley ${ }^{1,2}$ (D) \\ 1 PreKindergarten Program, Buckingham Browne and Nichols School, Cambridge, MA 02138, USA; \\ dbentley@bbns.org \\ 2 Early Childhood Education Program, Lesley University Graduate School of Education; Cambridge, \\ MA 02138, USA
}

Received: 18 September 2019; Accepted: 20 January 2020; Published: 31 March 2020

check for updates

\begin{abstract}
What is the role of mothering in the early childhood classroom? Given the focus of the field of "professionalization" and "scientific" practices, how might the role of maternal nurturance be woven into our understandings of pedagogies? This paper addresses the disempowerment experienced by an early childhood practitioner when maternal subjectivities and practices are framed as oppositional to the "professionalization" of the field. Through narrative research as a teacher-scholar, I explore my own experiences around my role as "not-mother" in the classroom, looking critically at the interwovenness of mothering and teaching in classroom relationships and communities. Through this narrative examination, I explore the role of maternal relationships in early childhood, in conversation with my practices of mothering as the teacher-not-mother. Through narrative inquiry and analysis, I attempt to make visible the forbidden subjectivities of the not-mother, and her centrality to meaningful early childhood pedagogy.
\end{abstract}

Keywords: early childhood; pedagogy; motherhood; narrative research; teacher as researcher; feminism

\section{Introduction}

Spring- Goodbye Season

It is spring in PreK, and goodbyes are imminent. I avoid the calendar, our end drawing nearer each moment. This parting is my teacher fate, the certitude of goodbye, no matter how close the bonds. I am the not-mother, the woman who mothers, who teaches, who hand-holds, who soothes, and who says goodbye. I am everything and nothing. We are a world together, the teacher-not-mother and her children, yet our bond is unspoken, our world just a moment in their unfurling series of school memories. "They are mine!" my insides cry, yet I hush these internal protests, preparing for separation, knowing that this impending break is the required rhythm of the school story. As the spring flowers bloom, I brace myself for the finality of goodbye. My children, who are not my children, are leaving.

This paper examines the maternal role of teacher as "not-mother" in the early childhood classroom. As a classroom teacher-scholar, I argue that the particular nurturance, care, and affection of mothering are critical elements in the thinking and learning of young children (Recchia et al. 2018; Osgood 2012; Osgood 2006; Goldstein 1998a). As a not-mother/practitioner/scholar, I place my subjectivities in a space in between and amidst discussions of professionalization, "natural care", and "ethical care" (Ailwood 2008; Osgood 2006; Hoagland 1990; Goldstein 1998a; Noddings 1984). Positioned from within the early childhood classroom, I wonder:

- How might we weave "professionalism" and maternal care into the roles of early childhood practitioners? 
- Is there space for us to be both maternal and professional?

- What possibilities does the role of not-mother create as an early childhood practitioner? What limitations does it impose?

Positionings: Identity(ies) in Which these Stories are Conceived

As we move forward into the body of these subjectivities and stories, I want to be clear about my subjectivities and how they operate in this space. I am a cis-gendered, white woman of privilege, and these realities shape the constructs and stories of motherhood(s) that are put forth in the context of this paper. Constructs of mothering are raced and classed, and my subjectivities offer particular lenses as well as limitations (Collins 2000; Case 1997). In this paper, I attempt only to address the mothering subjectivities that are available to me through my experiences, recognizing the limitations imposed by my positioning in the world.

\section{On the Use of the Word "Mother": Status and Stance of the Almost-Mother in ECE}

I fluidly use "mother", "maternal", "mothering", and "motherhood" in the context of this paper. I realize that I could call it something else. I could use a term more palatable, more acceptable in the larger conversation of education. You could call it the "ethic of care" (Noddings 1984), or any other, more acceptable term. More "professional". And yet, as a practitioner, those palatable words are not enough. And they are not mine, not of me and my practice.

For this paper, I conceptualize the above terms (mother, motherhood, mothering, and maternal), as the particular ways in which nurturance, care, and love are intrinsic to foundational relationships in early childhood spaces (Recchia et al. 2018). This work of mothering is not limited to those who identify their gender subjectivities as female, yet mothering is deeply entangled in the social construction of female subjectivities (Arendell 2000). This entanglement with mothering is extended to all those who do this work of nurturance with young children, including (but not limited to), those who identify as female, male, or non-binary. No matter our gender subjectivities, all of us who engage in this work participate in constructs of motherhood(s) through our practice with young children (Chodorow 1989). In the context of this paper, I identify these terms of mother, maternal, and mothering (and those associated) in the light of Arendell (2000) examination of motherhood, "Definitions of mothering share a common theme: the social practices of nurturing and caring for young children. Mothering, thus, involves dynamic activity and always-evolving relationships" (1192). While this paper does not attempt to delve into the complexities of the literature on the subjectivities of mother, the concept of mothering(s) represented in these pages falls within the construct of motherhood(s) as engaging in this practice of care, nurturance, and relationships around the care and raising of young children (Arendell 2000).

Glenn et al. (1994) position mothering as a particularly powerful social construction. Forcey (1994) identifies mothering as, "the main vehicle through which people first form their identities and learn their place in society" (357). This framing of mothering is central to the work represented in this paper, as it positions early childhood educators as empowered in this process of subjectivity-forming with young children, acting within one construct of mothering.

Silencing the word "mother" in the work of early childhood has the effect of both denying power as a practitioner as well as denying access to feminism(s). Early childhood educators are predominantly female (Osgood 2012), and the profession itself is highly feminized; its origins are in conceptualizing motherhood as a woman's vocation, that vocation made public through work as a kindergarten teacher (Fröebel [1844] 1980). With the "professionalization" of the field, practitioners are regulated, and often silence the emotional, maternal elements of teaching in favor of a "scientific" perspective (Ailwood 2008; Osgood 2006; Bloch 1992; Hoagland 1990). To be "professional", I must silence the overtly feminine, the mothering in my profession (Osgood 2012; Jones and Osgood 2007). Therefore, I find that to be professional, I must appear more masculine. To be masculine, I must silence my maternalism. And in silencing the maternal, I quiet my subjectivities and the root of my power as 
an educator. These intersecting dissonances of subjectivity and expectation render me silent and bewildered, in an eternal dance of appeasing the regulatory eye and hushing the feminine selves not approved under the dominant regulatory gaze of the moment (Butler 2006, 1993). It is a space of constant insecurity, of wondering which selves are "approved" and which must go underground, operating in silence for the good of the children, but always quiet and fearful under the regulatory gaze. In this paper, I position myself amidst the dissonances of contradictory selves, using narrative to seek ways in which they might play nicely together.

And so yes, I hear the protests. I understand the other, easier words for what I do, for what I am. I hear them, yet they are not mine, and they are not enough. I will say, "mother". I will call myself "not-mother". Because those words, their words, are not enough for me.

\subsection{Female Subjectivities and Politics in Early Childhood Education (ECE)}

\subsubsection{In Defense of the Not-Mother}

In conceptualizing, I struggled to develop a term for the work, the language that would encompass the shape of the mothering relationships in my classroom practice. While aware of terms such as "professional love" (Page 2018) and the complexities of "othermothering" (Case 1997), none of these terms encapsulated the shape of the subjectivities and relationships I attempt to represent in this paper. Through this process, I developed the term "not-mother" to conceptualize the particular experiences of this space that I occupy in the classroom. I choose this term because of its conflicted relationship within itself. The all-consuming nature of "mother" exists connected, yet in contrast, to the negation of "not". We (those who teach young children) are mothers, yet, simultaneously, we are not. We exist in a space of asserted and negated subjectivities, as we participate in the consuming practice of mothering (Arendell 2000), while aware of our "not-ness", and the reality that these children are not, in fact, our children. This experience of "not-mothering" in early childhood has a particular relatedness to the progression of the children endlessly entering and exiting our classrooms. "Not-ness" is critical to our mothering, for we are forever connecting with these children, with our eyes on the horizon of their necessary exit from this relationship as they "advance" to the next grade. As a teacher, it is a constant state of profound connection and mourning, as I carry both the pressing need of the current relationship, as well as the fast-advancing expectation of the cessation of their need for me.

This role of not-mother, she who teaches and mothers, who nurtures and challenges, is central to my subjectivities as an educator (Ailwood 2008). It is on this foundation that curricula and community are built with children. There is a forbiddenness to this not-mothering, something that cannot be named, yet is critical to early childhood practice (Page 2011; Hoagland 1990). "You are safe. I too, am your mother," is my unspoken whisper to the children, this subjectivity always consigned to the shadows.

\subsubsection{Not-Mothers and Othermothers: Intersections and Divergences}

In conceptualizing the notion of the not-mother and how this concept operates in my subjectivities as a white, early childhood educator, histories of the othermother (Collins 2000; Case 1997) both intersect and diverge with the my not-mothering. In the context of this paper, the concepts of not-mother and othermother operate in conversation with one another, neither encompassed by nor in opposition to each other, but deeply connected and profoundly diverging from one another. Patricia Hill Collins (2000) and Karen I. Case (1997) trace the othermother through histories of Black women in the United States, making visible the story of the othermother as emerging from slavery, oppression, and racism in the U.S. Collins (2000) explains, “ . . the African-American cultural value placed on cooperative child care traditionally found institutional support in the adverse conditions under which so many Black women mothered," (p. 179). While my maternal subjectivities are connected to the othermother through the mothering of children who are not biologically/legally mine, my histories and experiences as a white woman in early childhood signaled to me the need for a 
different term. Othermothering is frequently used in the raising and racial defense of African American children (Roop and Henward 2020 this issue). As a white woman, my not-mothering exists with different foundations and aims, and I cannot claim othermothering in this context, despite the many connections. I, as the not-mother, do intersect with critical elements of othermothering, related to the practice itself-the texture, the connection, the rhythm of these relationships. In her study of African American othermothering in schools, Case describes, "Othermothering as it relates to teaching is a matter of 'responding to and reacting with the students ... They have to feel not only just your voice. They have to feel the warmth and caring that comes from you as a person,'" (p. 35). My subjectivities as not-mother do not carry the racial identities of the women represented in this study, yet they are deeply related in the description of the critical relationships, the emotion and connections constructed through maternal feeling. However interrelated these terms (not-mother and othermother) may be, the distance between them is great, as the othermother exists in an unfolding historical context around race, oppression, community and survival, distinct from my not-mothering experiences as a white teacher. These two concepts, othermother and not-mother, are deep in conversation with one another, resonating and connecting, but in the context of this paper, I have chosen to use not-mother to describe my particular experience as a white, female, early childhood teacher.

\subsubsection{On Being "Professional”}

In a time of "scientific" "professionalization" of our work, this subjectivity of the not-mother is predominantly silenced (Page 2011; Osgood 2006; Bloch 1992). There are complexities inherent in this process, as connections between mothering and teaching have often been used to deprofessionalize and oppress early childhood educators (predominantly identifying as women), through low wages, low status, and a denigration of skilled work as purely instinctive (Osgood 2012, 2006; Cannella 1997). Through layered narrative inquiry (Chase 2005) as teacher/mother/scholar, I approach this forbidden subjectivity that weaves its way into the powerful everydayness of classroom mothering. In these narratives of the curtailed forevers, of not-mother and child, I examine the entangled genealogy of the early childhood teacher.

A much wiser person once warned me that I should consider the "so what-ness" of my work. This phrase lives with me always, calling me out and calling me back to the purpose of writing. So, so what? Why do these words, these stories matter? Because I need space for my subjectivity. I need a place to put my story of not-mother in the larger conversation. And if I need this, then perhaps others do too. While I know that these narratives are my stories, they are also small segments of a more extensive web of not-mother stories (Dyson and Genishi 2005). And while I would not presume to speak for others and their experiences (Osgood 2010), I know that I am not alone in my subjectivity, and maybe, just maybe, putting words to this self and speaking them aloud will help to further carve out space for other not-mothers in the field.

\subsubsection{Genealogy and the Not-Mother}

The Foucauldian notion of genealogy is deeply connected to both the narratives that weave the content of this paper and the silences that generate the need for these narratives (Foucault 1972). In the context of this paper, language is framed as weaving reality(ies), typically through discourses constructed by those in power (Henward 2018; Foucault 1972). These discourses shape how women are normalized and regulated in early childhood, through Foucault's "regimes of truth" (Gore 1995), which determine both language and silence, and the told and untold histories that are constructed through these regimes (Henward 2018; Foucault 1972). Henward (2018) explains, “ . . this power is diffused; it operates through the unconscious, day-to-day practices of individuals, reinforced and authenticated by our daily discursive practices ... " (233). This paper represents a highly personal genealogical tracing of discourse around mothering in early childhood, and narratives that interrupt a "regime of truth" (Gore 1995) to make space for a critical subjectivity that is predominantly regulated and silenced. 


\section{Theoretical Approaches}

\subsection{Dissonant Intersections}

The construct of teacher/woman/mother/not-mother in the context of this paper operates in a sea of tensions and dissonances, all interwoven within the subjectivities of an early childhood teacher. These subjectivities interweave, yet battle each other from within, creating the conflicted yet connected subjectivity of woman/early childhood teacher (Butler 2006). The challenges and textures of these dissonant intersections center around the regulation of women, their bodies, and how they are allowed to "do gender" (Hill 2002). These issues are particularly complex within early childhood education, a field dominated by women engaged in the care of young children (Osgood 2012). Originally conceived of as a maternal endeavor (Fröebel [1844] 1980), the subjectivity of early childhood teachers has been contested over the years, with the science of "professionalization" (Ailwood 2008; Osgood 2006; Bloch 1992; Hoagland 1990) operating in opposition to the teacher as a mother. The bodies and identities of the early childhood teacher become a battleground for essentialist notions of woman, who must be either mother or professional, her (my) subjectivities constricted and regulated by an external, masculine gaze (Butler 2006). This paper exists amidst these dissonant intersections, in an ever-changing space of seemingly contradictory identities. These identities, oppositional though they may seem, are intertwined within a professional who is a teacher of young children, a mother who is not-mother.

\subsection{Brief Histories of the "Professional" Early Childhood Teacher}

When considering the role of the maternal or "love" in the early childhood classroom, there are compelling arguments for the importance of maternal care in the thinking and learning of young children (Recchia et al. 2018; Goldstein 1998a; 1998b; Noddings 1984). Noddings (1984) notion of the "ethical care," providing a space for the role of maternal care within the professional subjectivity of the teacher is a concept that was taken up by others such as Goldstein (1998b), seeking a framing of maternal nurturance in the classroom that was also critical and professional in nature.

This is a theoretical space of some dissonance, as the fear of the deprofessionalization of early childhood teaching enters the conversation, as well as the need to frame the development of young children in the realm of the scientific (Ailwood 2008; Osgood 2006; Bloch 1992; Hoagland 1990). Within this theoretical realm, concepts of the maternal can be framed as oppressive and limiting to skilled educators of young children (Ailwood 2008). These concepts of "mother" and "professional", so often framed as being at odds with each other, create a disquieting dismemberment of those of us in the field, which embody both, and yet must somehow choose sides in a battle within our bodies (Osgood 2006).

\subsection{Intersecting Identities. Narrative Constructions}

Madeline Grumet (1988) reflects:

Despite my identification with the Left's interest in social justice, somehow, their serenade to society left me no part to sing. The experiences of family life, of bearing, delivering, and nurturing children, were absent from this discourse. Silent too was the language of the body, the world we know through our fingertips, the world we carry on weight-bearing joints, the world we hear in sudden hums and giggles. (p. xv)

The narrative perspectives represented in/constructed through this paper (Richardson 2005), speak to Grumet's above words, the existence of the not-mother who is regulated and silenced by her would-be saviors and their offers of "professionalism" (Osgood 2006; Bloch 1992; Grumet 1988; Foucault 1979). Osgood (2006) speaks of a "powerlessness and fatalistic resignation" in which teachers "seem to be embodying or performing a given policy intention, but they neither believe in it nor feel able to resist it" (p. 7). I place the experiences represented/constituted (Richardson 2005) in this paper within these tensions, in the dissonance created by outside institutions attempting to regulate my 
body/voice/practice through highly political, institutionalized concepts of "justice", "professionalism", and "advancement" (Osgood 2010; 2005; Grumet 1988).

My narratives are situated amidst these theoretical conversations, wondering if there might be space for both the professional and the maternal, the nurturing, and the critical (Recchia et al. 2018; Goldstein 1998a). Goldstein (1998a) argues that we might, "take the love that already exists in many early childhood classrooms and place it on equal footing with more traditional and official sources of knowledge" (p. 27). I wonder further, might the professional also be maternal? As a not-mother/practitioner/scholar, I position my subjectivity and experience within/amidst these theorists, seeking a space and a voice for the professional and maternal perspectives that I entangle in my pedagogical stance.

\subsection{Methodology and Approaches (Material and Methods)}

Who are we? Where are we?: The Children, the Teacher, and our Environment

While I would not attempt to adequately represent the diverse identities at large in my PreKindergarten classroom, I would like to offer a few details on the participants and contexts that are at large in this paper. Our narratives occur in a PreKindergarten classroom in Cambridge, Massachusetts, in the United States. In our community, PreKindergarten encompasses ages four and five, and the class is made up of sixteen children.

I have been a teacher in this classroom for ten years, and have been teaching young children for eighteen years. In this classroom, I remain with the children for their entire day, which is from 08:00 to 15:00 h, with occasional visits to a music or library classroom during which I am away from the children for about twenty-five minutes. This may seem like unnecessary detail, but it is important to note the connectedness that is born of spending six to seven hours a day learning and working as a classroom community. Our classroom practices an emergent curriculum in which we grow curricula out of the play and interests of the children, relying heavily on the observation and documentation of children's play to guide our understanding as practitioners, and our relationship with the children (Edwards et al. 1998).

\section{A Methodological Mess}

It is late Sunday night, and I sit at the computer, typing furiously, words pouring onto the page. This idea of an article about mothering ignited something, and suddenly I found the stories raining down on me in every moment of my teaching day. "Finally," my whole body seemed to sigh, "write it down." And I would write and write, and then delete, slam the computer lid shut, pretend I never said it. These were forbidden things I was saying, these words of mothering in the classroom.

In practical terms, this paper is a narrative examination of my role as not-mother, framed as a situated, yet representative, instance of the intertwined experience of mother and teacher in the early childhood classroom (Dyson and Genishi 2005). "Data" for this paper are constructed from narrative inquiry (Chase 2005) into my classroom experiences and practices. These "data" were collected several times a week and were (re)constituted as narratives through practitioner research (Gallas 1994; Paley 1984), using Richardson (2005) lens of "writing as method". These "datapoints" were recorded at times experienced as "hot points", (Cahnmann-Taylor et al. 2009) for me, moments that demanded to be told, and had me scrambling for my phone to add yet another list of cryptic terms to my "notes" function, while gathering sand toys, extracting a splinter, and discussing the pros and cons of "letting the flowers grow" instead of picking them. Can notes, hastily typed with sandy fingers amidst a cleanup melee, qualify as "data"?

I place my work amidst a rich conversation of teacher-researchers for whom writing offers understanding(s), voice(s), and emancipation(s) (Yelland and Bentley 2018; Souto-Manning and Martell 2016; Pinedo-Burns 2015; Cuffaro 1995; Gallas 1994). I place my narrative inquiry (Chase 2005) within a complex history of scholarship in and around the role of mothering in early childhood 
education (Fröebel [1844] 2005; Pestalozzi 1951; Montessori [1856] 1912). For this paper, I will not attempt to represent the fraught complexities of the role of the maternal in the history of the field of early childhood education. Instead, I focus on the discourses on mothering and professionalism in early childhood, and how these concepts operate when placed in opposition to and conversation with each other (Osgood 2006; Osgood 2012; Hoagland 1990; Goldstein 1998a; Noddings 1984). This paper is a narrative wondering toward wholeness, toward a place in which the maternal and professional might allowed to be encompassed by one pedagogical/maternal body: my own (Grumet 1988).

Storytelling is the academic precursor at every level of instruction. The imagination begs to be used at every age and stage of life; it frees the mind of rigid patterns and allows us to visualize new approaches to old questions, moving us on to new possibilities. "What if" and "pretend that" are the motivational devices we require to move beyond self-imposed limitations as well as those levied on us by convention and convenience. (Paley 2009, pp. 130-31)

In considering the role of teachers and narrative inquiry, I begin with these words by Vivian Gussin Paley, the woman who gave me permission to write of, in, and through my classroom. I frame my narrative work within the emancipatory experience she presents here, one in which the teacher/writer is empowered to move beyond limitations (however they are imposed), and into the experience of knowing, re-knowing, and coming to understand through the constitutive process of writing (Richardson 2005; Dyson and Genishi 1994). There is something essential about the nature of this writing process and what it brings to the experience. Paley (2009) explains, "Writing about play and story can become a teacher's form of play" (p. 134), and this is the nature of the constitutive work that I experience through narrative inquiry (Richardson 2005). In the context of this paper, I construct narrative as a place that is both emancipating and constructive, allowing me to access/constitute elements of experience while resisting the silence that often enshrouds classroom teachers (Christianakis 2008; Richardson 2005; Greene 1973)

\subsection{Narrative as a Feminist Methodology}

As I shape and am shaped by these narratives, I am particularly influenced by the practice of pedagogical narration (Pacini-Ketchabaw et al. 2014; Berger 2010). I find pedagogical narration an essential tool because of its intentional creation of spaces of resistance, critical to revealing the obscured practices of mothering in the classroom. I understand teachers' voice to be an inherently feminist issue, as "nursery work is both gendered and classed" (Osgood 2012, p. 102); early childhood education is a profession dominated by women who are offered little voice in more significant conversations regarding theory, regulation, and standards (Osgood 2012; Christianakis 2008). Early childhood is a productive space of voice until we step outside of the safety of the classroom. Once we emerge from that space, our silence is expected and often demanded by the, "professional institutions and practices that have generated disciplinary and regulatory powers over teachers (who are mostly women) and children" (Cannella 1997, p. 137). Finding a critical voice for teachers is a feminist endeavor, a space in which we, as practitioners, may reject the regulatory gaze that tells us to be "good" and "normal" (Cannella 1997, p.137), allowing us to wander toward our own, ever-becoming feminist identities (Beauvoir 2011). As such, I seek out the practice of pedagogical narration in an effort not only to have a voice, but to shape a view that is empowered to reject, to re-conceptualize, re-imagine, and to reconstitute the life of the classroom and the layered identities within. Berger (2010) states, "these narratives provoke us to think anew and to resist normalized and habitual conceptions of children, education, learning, and assessment" (p. 58). The framing of narrative as a political act through pedagogical narration allowed me spaces of resistance and defiance as I worked to make sense of these entangled experiences of not-mother in my pedagogy. 


\subsection{Tensions of Role and Subjectivity in ECE}

ECE is a field grounded in feminism(s). Miller (2005) writes of her role as teacher, “... I now understand that one conception of myself as 'good girl' and 'productive woman' rested on my perceived abilities to give to others, to do something in some way to help, to enrich, to embellish others' lives" (p. 73), and I situate myself similarly, in that desire to be "good" as constructed by the masculine eye, that goodness resting in relation to others and the services I can provide (Butler 2006; Miller 2005). And yet, what if the desire to give/teach remains? What if the desire to mother (or not-mother) is present as well? Is there space for this feminist subjectivity, a subjectivity that "helps", "enriches", and "embellishes" through choice and power rather than compulsion? Miller goes on to say, "... in my ironic desire to please, to receive authorization, I effectively denied or erased parts of my self" (Miller 2005, p. 103). Thus, I would characterize my relationship with feminism(s). To be "authorized" as feminist, I perceived that I would need to deny my subjectivity as an early childhood teacher (caretaker, not-mother). That being impossible, I denied my status as a feminist. I am only now coming to understand the space that feminism(s) hold for the not-mother.

For the purposes of this paper, I take up feminism(s) in the light of Judith Butler (2006) work, as a space of broad, ever-emerging subjectivities. I am claiming a small corner in the realm of feminism(s), one that the not-mother might be able to inhabit. Looking to Butler (2006), I conceptualize my role as a feminized one, one that is performed; I look to a feminism that is expansive and ever-becoming, rather than feminism as constructed and defined concerning traditional masculine power. In Butler (2006) words:

... any feminist theory that restricts the meaning of gender in the presuppositions of its own practice sets up exclusionary gender norms within feminism, often with homophobic consequences ... feminism ought to be careful not to idealize certain expressions of gender that, in turn, produce new forms of hierarchy and exclusion ... the aim of the text was to open up the field of possibility for gender without dictating which kinds of possibilities ought to be realized. (p. viii)

This space of feminism(s) as diverse identities that are ever-becoming is the place in which I would situate the narratives and experiences in this paper (Butler 2006; Beauvoir 2011). The subjectivities of the not-mother are framed in the light of the notion that, "woman itself is a term in process, a becoming, a constructing that cannot rightfully be said to originate or to end" (Butler 2006). I would place these narratives in this feminist construct of the woman becoming, reflecting on/rejecting the regulatory structures that attempt to produce/reduce her identity, while reclaiming the ability to, " ... do professionalism in ways that are instinctive, intrinsic to the nature of the work and foundational to providing appropriate emotional nurturance ... " (Osgood 2012, p. 118).

\subsection{The Silence of the Early Childhood Teacher}

Early childhood education is a highly regulated space in which low-paid practitioners (predominantly women) are rarely offered a voice in the construction of their professional role and subjectivity (Osgood 2012). Being a "good" early childhood teacher shifts with whims of the regulatory gaze, requiring that we reshape the outward performance of our subjectivities while silently sustaining the skills we know to be critical to our practice (Butler 2006; Osgood 2006). Our work as not-mothers falls victim to the constant regulation of our practice and our bodies, as (currently) verbalizing our maternal skills is forbidden (Ailwood 2008; Bloch 1992); thus, we are silenced. Mother, not-mother, maternal, professional, scientific, and nurturing - as we perform our gendered profession (Butler 1993), the very shape of our silences shift in response to the newest regulatory demand that redefines how we can continue to be "good girls" (Miller 2005).

When maternalism is positioned in opposition to feminism, and to the professionalization of the field of early childhood (Osgood 2012; Hoagland 1990), a bizarre gag order is created for those of us in the classroom, who perceive ourselves as professional, maternal, and feminist (Butler 1993). The effect 
is that, methodologically, the narrative inquiry in this "study" (Chase 2005), is alive, subversive, and constituting "truths" to me that I did not know that I held (Richardson 2005), so obscured are they by my desire to be a "good girl", (Miller 2005) a "good teacher", (Greene 1973) and to hold myself to the "scientific/professional" (non-maternal) expectations of the field (Osgood 2006). Thus, as the narratives are constructed, so are new "truths" constituted (Richardson 2005), a process of (re)remembering what I thought I knew of myself and my practice as a not-mother in the field of early childhood education.

Findings: "Finding" the Not-Mother, Finding Ourselves (Results)

Findings in this paper are ever-unfolding as I examine my experiences of not-motherhood in the early childhood classroom. Again, I find myself in the amorphous place of Butler (2006) feminism(s), "to open up the field of possibility for gender without dictating which kinds of possibilities ought to be realized", (p. viii). As a woman accustomed to orienting herself in response to the regulatory (masculine) gaze (Osgood 2012; Butler 2006), it is a disorienting space, a place where the "good girl" (Miller 2005) attempts to locate her dismembered pieces and place them in conversation with each other. To tell the professional that she is maternal, the not-mother that her maternity is entangled in her profession is a disorienting experience. As I engage(d) in this process, I fight to quiet the external commands, commands that say that this is too personal, too emotional, too erratic for academia, for a professional (Osgood 2012). I want so much to be a "good girl" (Miller 2005), a "good teacher" (Greene 1973). The forbidden-ness of the maternal has an obscuring effect, such that new realizations emerge as I engage with the "data" (Goldstein 1998a), a process of finding motherings in spaces where I had hidden them even from myself. The slippery, difficult-to-find "findings" are represented below with lenses and overlays that I told and were told to me through the recursive process of writing them (Richardson 2005). Through them, I wonder anew and question. Through them, I ask us all, is there a place for me? And could I be the one to decide?

\subsection{A Guide to Findings}

I organize the "findings" in this paper around narrative vignettes from the classroom, followed by lenses of analysis on these particular narratives. I label them with the name of the vignette and the associated analytical lenses:

\section{Findings Vignette: Fall- The Transfer}

a. Fall- The Transfer: Subjectivities and the Interweavings of Knowledge and Instinct;

b. Fall- The Transfer: Dichotomy(ies) of Trust and Rivalry.

2. Findings Vignette: Winter-Losing My Child, Being Found by "My" Children

a. Winter- Losing My Child, Being Found by "My" Children: Reciprocity(ies): Reciprocal Relationships of Care Between Children and Teachers Spring-Everyday Heroine-isms: The Maternal Nature of Textured Knowings.

\section{Findings Vignette: Spring- Everyday Heroine-isms}

a. Spring-Everyday Heroine-isms: The Maternal Nature of Textured Knowings

Findings Vignette: Fall- The Transfer

It is a Monday morning in late September in the PreK room, and the honeymoon period has ended. The children have reached the end of the rose-colored early days of school, and have not yet entered the comfort and strength of their everyday occupation of the school space. Their rhythm and security will come, but not yet.

On this morning, Hazel is carried into the classroom by her mother, both of their faces studies of distress. Mondays are hard. Goodbyes are hard. Late Septembers are hard. I can feel my heart chime 
as I look to them; my whole body resonating with empathy for the pain they are experiencing. I am calm in the certainty that I can help; I will get them through this. I wait for a moment, letting them cling to one another. Then, instead of reaching for Hazel, I gently place my hand on her mother's arm, saying, "Let me know when you are ready." Her eyes fill with tears, and she chokes out abruptly, "I'm ready now."

I lift her daughter out of her arms, and Hazel transfers her embrace, wrapping herself around me like a koala, clinging to me and crying. "It's ok. I promise I will take care of you. I know you're sad, but it will be ok," I croon to both of them. As her mother struggles to walk away, I say, "I will email you to check in as soon as I can. I won't let you worry. I promise." Her eyes meet mine, softening in relief as her daughter's face burrows into my shoulder. With that, she makes her way out of the room as I soothe her child.

\section{Fall- The Transfer: Subjectivities and the Interweavings of Knowledge and Instinct}

As evidenced by the above narrative, the role of the not-mother is one of intensity in the early childhood classroom. There is an interwovenness of knowledge and instinct that are activated in these moments, placing me (as the teacher-not-mother) in both a professional and a maternal space (Goldstein 1998b). I respond with pedagogical history, with knowledge of the particular time of year, day of the week, and historical understandings of what this means for the child (Aslanian 2015). Simultaneously, I respond as not-mother, soothing, rocking, crooning, certain of my ability to care this child (Recchia et al. 2018). There is a devotion and certainty that surges through my body in these moments, and the integration of these two perspectives seems to exist at the intersection of Noddings (1984) "ethical" and "natural" care. It is both. I am both. I would argue that both the child and her mother can feel these simultaneous assurances, the teacher and the not-mother, responding with professional knowledge and emotional nurturance. It is this intersection that allows the child to make the transfer to me, and the mother to ultimately walk out the door.

The Transfer: Dichotomy(ies) of Trust and Rivalry

Another complexity in this role of the not-mother is the dichotomy of trust and discomfort experienced by the actual mother in relation with the not-mother. (Page 2011). There are complex dissonances wrapped into this seemingly simple act of "the transfer," in which the nurturing ability of the not-mother is both needed and discomfiting in this collaborative care for the child. The mother needs to know that I can comfort her child. She needs to know, to feel confident that I will be able to fill the maternal role in her absence; this allows her to walk out the door. Yet, there is necessarily fear and discomfort towards one who mothers your child when you are not present (Page 2011). While the mother feels comfort at the teacher's ability to comfort, so does she experience a loss that the not-mother has that ability (Recchia et al. 2018; Page 2011). The not-mother must live within this dichotomy, this dissonance of knowledge that her talent is also the source of pain. The silencing of the maternal subjectivity of the not-mother adds another layer of conflict at this moment, as the maternal subjectivity of the teacher is forced underground (Osgood 2012). The regulatory silencing of mothering in the early childhood context renders these women, these mothers, and not-mothers, suspicious of and distant from one another, both aware of the forbiddenness as well as the necessity of the not-mother in this moment of transfer.

\section{Findings Vignette: Winter-Losing my Child, Being Found by "My" Children}

When I arrive at school that morning, the remains of my baby are leaking from between my legs. The DEC was yesterday. I think, "This time should be easier. I didn't even hear the heartbeat before this one was lost. I never saw a picture. Eight weeks is less than twelve weeks. Less time to get attached, right? It was never meant to be. I already have two kids. I have no right to be upset. I'm fine. I'm fine. I'm fine, fine, fine, fine." These strange thoughts spin through my head as I start taking down the chairs in my classroom and feel another gush of blood. 
There is an odd sense of impossibility in these moments. The world couldn't possibly be just the same, could it? I won't find the same people at the coffeemaker, discussing the same topics of winter break, school reports, and the lack of milk in our fridge. There's been an earthquake; can't they see? But they can't, of course. And I make my coffee, stir in the Splenda, and I bleed.

Eight o'clock comes quickly, and a wave of children is outside the classroom door awaiting me. I move to open it, thinking again of impossibility. They can't possibly expect me to do this now, can they? I feel sure I am not up to it, will not be able to do my job. I pull the door open, and the wave of them rushes into the room. Not them, as something other or foreign, but them as in us, as in our, as in we. There is a we that rushes into the room, and into me and suddenly, soothingly, amazingly, I am brought back to myself. The typical patter and hum of the morning routine capers around me, tiny hands reaching, not-so-tiny voices demanding my attention. I'm unzipping coats, holding hands, locating name clips, and kneeling to read the morning message quietly into a small ear. I am still bleeding. But somehow I have become we.

All through the day, the children carry me. They know nothing of my loss, yet they know everything. They and I are we, an unbroken circle of nurturance and care, love and consolation. Just as I read the cadence of their steps, the look in their eyes, the tenor of their voices, so do they read mine. I am part of their "we". I, the not-mother, am part of their family. And I get care too. Our day together is a blanket of normalcy; the routine carefully constructed to soothe those who are smaller soothes the not-mother as well. I notice the small bodies leaning against me. A gentle hand on my shoulder. A reach for a Mo Willems book at storytime, "Because Dana likes to do the voices." A tumble into my lap, followed by the signature "nestle" move, to make sure we fit together just right. All of this is normal. It is part of our routine. And yet it is also their nurturance, their care in the face of my silent scream. For though it is quiet, as I smile, sharpen crayons, apply Band-Aids, and read books, they hear it all the same.

I am theirs. And these children are mine. And I am still bleeding. But I am not alone.

Winter-Losing my Child, Being Found by "my" Children: Reciprocity(ies): Reciprocal Relationships of Care Between Children and Teachers.

I was terrified to put the above words on a page. I sat down to write them again and again, always slamming the laptop closed, appalled at my audacity. We do not speak of miscarriage. It is just not appropriate. Miscarriage is the stuff of awkward silences, uncomfortable looks, cleared throats, and limp, "I'm sorrys." Only the weak and emotional give airtime to the dead babies that they never knew (Butler 1993). So imagine the inappropriateness of the above intersection: miscarriage and school. Miscarriage, and early childhood. As I experienced this, as I wrote it into experience (Richardson 2005), I practically choked at the sheer wrongness of it, a woman naming her loss, worse, a teacher bringing her loss into the classroom and, still more offensive, a teacher seeking comfort from her students. These stories, these selves are not permitted in the classroom, into these relationships, into this work (Osgood 2006; Grumet 1988; Foucault 1979). This is the work of dismemberment, in which the "good teacher" is conditioned to set the self aside, to sacrifice the person on the altar of vocation (Greene 1973). As Greene (1973) explains:

The teacher is frequently addressed as if he had no life of his own, no body, and no inwardness ... They are likely to define him by the role he is expected to play in a classroom, with all his loose ends gathered up and all his doubts resolved. The numerous realities in which he exists as a living person are overlooked. (p. 269)

Let us just say that, on entering the classroom that day, I was a mass of "loose ends", a study of intersecting "realities" that I deeply understood as separate from the classroom, but who made themselves at home in my classroom "we" (Dyson and Genishi 1994), with or without my permission. As the narrative unfurls, the classroom holds space for my grief at my loss of motherhood, while 
affirming my motherhood in my role as the not-mother. The needs of my not-children, while seemingly impossible, filled and soothed, bringing me "back to myself". While the loss was not spoken, it was carried within that classroom space, despite my attempts to further dismember my subjectivity, to leave the "inappropriate" at home (Greene 1973).

I want to speak now to reciprocity, and the essential nature of reciprocal love relationships between children and teachers, between me (the not-mother) and the students, (my not-children). Reciprocity is often absent in discussions around early childhood teachers due to the need to frame teachers as self-sacrificing and without emotional needs in the context of the classroom (Greene 1973). However, reciprocity between the child and the not-mother is critical to this examination of maternal nurturance in the early childhood classroom (Goldstein 1998a). The above narrative is a study in the forbidden reciprocities that populate the family that is the early childhood classroom. Indeed, the children did not know the details of my loss, nor would I ever share with them. However, I would argue that, due to our relationship and connectedness, they understood the weight of the loss I was carrying, as well as their potential role in nurturance in response. As these relationships develop, as mothering and not-mothering evolve, there is care in return. There is critical knowing, understanding of the highest kind, the knowledge of my favorite books, the perfect way to situate oneself in my lap, and the unspoken sadness in my demeanor. They know. And they care. And they carry me through this day, much as I bring them through their wobbliest of times. I place this moment, and so many others, in the light of Montessori (Montessori 1956) construct of children as agentive "love teachers" (p. 25) who participate in this reciprocal relationship with their not-mothers, providing mutual care as they receive care. In the context of this study, young children are seen as agentive and capable co-constructors of meaning (Rinaldi 2001); thus, their role in the relationship with the not-mother is also one of agency, teaching, and reciprocity.

Findings Vignette: Spring-Everyday Heroine-isms

It is a warm day in May (finally), and we are wrapping up an exceptionally long outdoor time on our playground. The kids' bodies were keening for the outdoors, after many months of extended New England winter, and so we barreled outside, waves of play washing over us with the warmth of the spring air. As we were about to head in, I noticed tiny Mira, silent, mouth turned down. She asked nothing. She spoke nothing. She stood, statuesque. Every part of her exuded her own, stoic kind of tragedy.

"Mira," I asked quietly, away from the group, "What's wrong? How can I help?" I leaned into a level of close-but-not touching, careful not to assume too much intimacy before she was ready. She was quiet for a moment, breath catching on unrealized tears in her throat. "My clip," she managed to whisper. I waited. Maybe there would be more, but I absolutely could not rush her. "Your clip?" I asked, finally.

"My butterfly clip!" she finally burst forth, her face desolate "It's gone!" I began a rigmarole of different places it might be, of checking cubbies and the classroom, as her face shut down. She was right; This was ridiculous. Mira was a master of self-containment, and she did not come for help unless it was truly needed. I could rest assured that the cubby and the classroom had been thoroughly inspected.

"Do you think you left it at PE?" I asked, with a sinking feeling.

"Yes," she said, brightening and slipping her hand into mine. "Can we go get it?"

To be clear, it was lunchtime. It was, in fact, way past lunchtime. There was a dirty group of disheveled kids needing food, and the gym was across campus. This was a time to delay, a time for "maybe later." But when that tiny, indomitable figure slipped her hand in mine, there was no helping it. I had to go.

After abandoning the class to my co-teacher, we hurried across campus to the gym, finding the clip just where she left it on the bench. I rushed as we walked back, needing to be in the classroom, as Mira 
happily told me about the gem in her hand, green on one side, yellow on the other. Yet another treasure that had been produced from her pocket. As she hurried to keep up with me, Mira stumbled, just the tiniest bit. Her hand opened, and out tumbled the gem. It was a slow-motion moment as I watched it fall from her fingers and through the gridded metal bars of the storm drain that just happened to be right at her feet. I wanted to scream.

Mira looked around for a moment, confused. Where had it gone? She looked up at me, and I considered every possibility at my disposal. Could I lie? Could I tell her I didn't know?

Not even a possibility. Mira does not deal with misdirection, and she is not distractible. "Honey," I said gently, "I think it went down the drain."

We peered down into the darkness together, and there, shining amidst the mud and leaves of New England spring, was the yellow side of the gem, twinkling away. Mira did not cry. If she had cried, maybe I could have said no. If she had cried, I could have given a talk about, "Sometimes we lose things, and that's hard." But that little girl gathered up every muscle, every measure of her strength in a brave, fierce, not-crying face and asked, "Can we get it back?"

How could I say no?

I had a 30-min break that day. I spent much of it fashioning a gem rescuer, made of a long pole, a bent spoon, and an immense amount of duct tape. When I finished, Mira led a band of us back to the site of the lost gem, wielding the "rescuer-stick" above her tiny head. Together we looked down to see it there, still twinkling up from the murk. Carefully, so slowly, I reached down with the pole and scooped the gem up. My hands trembled as I slowly pulled it up to the surface. I could not fail the tiny, fierce, not-crying Mira.

Finally, it was free. The group of kids erupted into cheers, so much that the big kids came over to see about the fuss. And Mira looked at me solemnly and said, "Thank you, Dana. I knew you could do it." With that, she pocketed the gem and ran off across the playground.

\section{Spring-Everyday Heroine-isms: The Maternal Nature of Textured Knowings}

When Madeline Grumet (1988) speaks of "the language of the body, the world we know through our fingertips, the world we carry on weight-bearing joints, the world we hear in sudden hums and giggles." (p. xv), she refers to the kind of maternal knowings that weave themselves through this narrative. It is such a simple story, a nothing really. I mean, who would even bother to write such a thing down? We found a hair clip and wasted a bunch of time finding a worthless, plastic gem. Certainly not worthy of mention. This is the stuff of mothering, or in this case, not-mothering, the silenced labor of knowing and understanding that is the fabric of relationships with young children (Butler 2006). The knowings, the silent understandings, and interactions of this shape and texture, these are the currency of our world of relationships. They are the truest, the most essential of exchanges in which we demonstrate to each other our in-depth knowledge and understanding of everyday needs and our willingness for those needs to shape our lives.

The above narrative is a labyrinth of knowings of maternal understandings of that particular child. Notice how seldom Mira speaks with traditional language. Her eyes talk instead. Her body speaks. My history with her speaks in these moments, and accumulated knowledge of self and need guide our interaction. Every choice I made that day was based on these subtle knowings, my role as Mira's not-mother, and how that knowledge shapes how I respond to her. I worked one-on-one with Mira in these moments, building the "gem-rescuer" and absenting myself from the class because this work of care and nurturance is critical to early childhood education. The mothering in this moment was not a departure from teaching but an active pedagogical choice embedded in the nurturance of early childhood work There were many more accessible, more "reasonable" choices that could have 
shortened the above interaction, each of which would have returned me to more "practical" teacher pursuits. I can also tell you that any of these circumventions would have severely limited Mira's trust in me, and the evolution of our relationship. In our world, connections are constructed from the importance of hair clips and the recovery of sparkly treasures. It is not for me to dictate what is important to her.

It is just that this knowledge does not get to count in the outside world. As Osgood (2006) argues, "In neo-liberal discourses, there is little room for emotionality or such feminine characteristics that are seemingly unquantifiable or auditable" (p. 8). This knowledge is not allowed to matter. How can I "prove" the importance of these moments, of this little story? What is the quantity? Where is the "data" in my maternal knowing, and what are the replicable outcomes of duct-taped, spoon contraption rescues? I couldn't say. I can only tell you that I know. I know what she needed in those moments, I knew the potential outcomes of my choices, and I was confident that honoring her plastic hair clip and the rescue of her sometimes-green, the sometimes-yellow gem was critical to her trust and connection with me. I knew. And what I knew in those moments, it mattered. It mattered to her. Her quiet, solemn, "Thank you, Dana. I knew you could do it" was worth everything. It was the world, encompassed in nine precise words and one small look.

As I consider this narrative, it seems to me that this work, this not-mothering, is all about what counts, what gets to count, what is valued as knowledge and power (Osgood 2005, 2006, 2010; Jones and Osgood 2007). While I know these moments above (and the many others they represent) to be the foundation of my practice, my pedagogy, to the world, they are something other-than-schooling, something outside of teaching, something less-than curriculum. They fondly call me "the baby whisperer" at school, as though this were some sweet femininity, an extra, outside of the realm of professionalism. And I would like to know, when does my kind of knowledge get to count? When will it be revealed that the not-mothering of the above vignette, the not-mothering of eighteen years of teaching, that is, in fact, my pedagogy? That is the curriculum. That is learning. It grows in the fertile space of listening, knowing, understanding, and mothering. It is written on the muscles in my biceps, strong from years of lifting crying children into my arms. It is written on my arms hanging by my sides, knowing that Mira is not ready for physical contact (Grumet 1988). It is written in carefully considered moments of speech and silence, moments for words and moments to make space for the words of the child. And I would like to know, when does it get to matter?

This small story makes visible the effective silencing of early childhood practitioners through the regulatory dictates of what counts as data, power, and professionalism. When the moments that constitute the relationships and learning of the early childhood classroom are dismissed to the outskirts, the emotional, the "baby whispering," they are stripped of their power, relegated to the status of "unskilled work" rather than the highly developed practices that they are

Significance and Implications (Discussion)

The discussion of mothering concerning the early childhood classroom is complex and ongoing. As we have sought the professionalization of the field and respect for our profession, the role of the maternal has been obscured and silenced (Osgood 2012; 2006; Bloch 1992). I experience this loss daily as an early childhood teacher who avoids verbalizing the skills that are the critical core of my work: the not-mother. These professional-maternal abilities build connections, sustain children and families through challenges, and shape every moment of pedagogy and classroom interaction (Recchia et al. 2018; Goldstein 1998a). As we move forward in these discussions, it is essential to include the voices of practitioners as scholars, sharing our experiences, our love, and our loss as the not-mothers of so many children. Perhaps, through these conversations, we will find space for the more complex, textured identities of the not-mother.

The notion of developing "conclusions" around experiences that are "inconclusive" is challenging. There is no end to these stories, to this subjectivity of not-mother as it unfolds over many years of teaching, and the unfurling of arrival and loss associated with the teaching of young children. 
Yet perhaps the conclusion itself is in words, in the power that they carry (Freire 1985) and the realities that words both construct and make visible (Richardson 2005). In attempting to "conclude," I find myself thinking of Freire (1985) words, "Reading is not walking on words. It is grasping the soul of them," and how they relate to these namings and narratives of not-motherhood. To simply express these words, to write them, to read them, to have them be understood, is an act of making unto itself, a making-of space for subjectivities as well as a challenge to the silence and disempowerment that so often accompany the role of the early childhood teacher (Osgood 2006).

Is this work significant? Maybe not. How could it be? These are the stories of one teacher, one not-mother, and her not-children. I feel the hubris of my telling them, or even hinting at the possibility that our everyday, my silent mothering, is significant to anyone else in any way. These are just the ravings of an emotional woman, better suited to the pages of a diary than the typeset of a journal. Aren't they? Yet, there is something about them, about my not-mothering, that feels critical. It is the key. That flash of knowing between the not-mother and the child, that confidence, that quiet reading of his eyes when he is getting sick, the sag of her shoulders when she is defeated, the tilt of her chin when she finds just the right word to express her thoughts, these are the trappings of the not-mother, of the early childhood teacher. These are my currency. They are unspoken knowings, readings of the cadence, the texture, the very breath of the child, the children, the classroom, and the children's absolute assurance in that knowledge. They are motherings, from the not-mother. And yes, they are significant. They are everything.

Summer- After Goodbye

I write this at the card table in my room, the space that serves as my desk and office during summer vacation. The ("my") children are gone, shelves have been wrapped in their plastic roles, and the meeting rug is free of crumbs, hibernating in its cleanliness until September. I run my finger over the class list that is still taped to my computer, thinking of them and wondering. There is such a strangeness to these goodbyes, to the dissolution of the family. Ours is a world of such permanence and everydays, of such connectedness and knowing, yet it is entirely impermanent as well. They are gone, and the air around me is quiet, clear, and full of loss.

I tell their families to send me pictures. I ask them to keep me updated on the first loose tooth, the swimming lessons, the health of the Venus-fly-trap, and the summer camp adventures. I have been a party to the intricacies of their lives every day. I desperately want to know what happens next. The families smile kindly at my interest and engagement with their children, but they seldom email. They rarely send pictures. Maybe they think I am pretending?

And thus, my not-children are gone, this year, every year. They will visit me perhaps, maybe self-motivated, but likely at the urgings of their families. They are no longer mine, and that is as it should be. I will always be their mother. I will never be their mother. And I watch them spool out before me into their adulthoods. I read their articles in the school paper. I clap until my hands burn at their school plays. I cry at their graduations. I am always waiting for them, their ever-present not-mother, there in the preschool classroom. Always mothering. Always saying goodbye.

Funding: This research received no external funding.

Conflicts of Interest: The author declares no conflict of interest.

\section{References}

Ailwood, Jo. 2008. Mothers, Teachers, Maternalism and Early Childhood Education and Care: Some Historical Connections. Contemporary Issues in Early Childhood 8: 157-65. [CrossRef]

Arendell, Terry. 2000. Conceiving and investigating motherhood: The decade's scholarship. Journal of Marriage and the Family 62: 1192-207. [CrossRef] 
Aslanian, Teresa K. 2015. Getting Behind Discourses of Love, Care, and Maternalism in Early Childhood Education. Contemporary Issues in Early Childhood 16: 153-65. [CrossRef]

Beauvoir, Simone de. 2011. The Second Sex. Translated by Constance Borde, and Sheila Malovany-Chevalier. New York: Vintage.

Berger, Iris. 2010. Extending the Notion of Pedagogical Narration through Hannah Arendt's Political Thought. In Flows, Rhythms, and Intensities of Early Childhood Education Curriculum. Edited by Veronica Pacini-Ketchabaw. New York: Peter Lang, vol. 45.

Bloch, Marianne N. 1992. Critical Perspectives on the Historical Relationship Between Child Development and Early Childhood Education Research. In Reconceptualizing the Early Childhood Curriculum. Edited by Shirley Kessler and Beth Blue Swadener. New York: Teachers College Press, pp. 3-20.

Butler, Judith. 1993. Bodies that Matter: On the Discursive Limits of 'Sex'. New York: Routledge.

Butler, Judith. 2006. Gender Trouble: Feminism and the Subversion of Identity. New York: Routledge.

Cahnmann-Taylor, Melisa, Jennifer Wooten, Mariana Souto-Manning, and Jamie L. Dice. 2009. The Art and Science of Educational Inquiry: Analysis of performance-based focus groups with novice bilingual teachers. Teachers College Record 111: 2535-59.

Cannella, Gaile S. 1997. Deconstructing Early Childhood Education: Social Justice and Revolution. New York: Peter Lang.

Case, Karen I. 1997. African American othermothering in the urban elementary school. The Urban Review 29: 25-39. [CrossRef]

Chase, Susan E. 2005. Narrative Inquiry: Multiple Lenses, Approaches, Voices. In The Sage Handbook of Qualitative Research, 3rd ed. Edited by Norman K. Denzin and Yvonna S. Lincoln. Thousand Oaks: Sage.

Chodorow, Nancy. 1989. Feminism and Psychoanalytic Theory. New Haven: Yale University Press.

Christianakis, Mary. 2008. Teacher Research as a Feminist Act. Teacher Education Quarterly 34: 99-115.

Collins, Patricia Hill. 2000. Black women and motherhood. In Black Feminist Thought: Knowledge, Consciousness, and the Politics of Empowerment, 2nd ed. Edited by Patricia Hill Collins. New York: Routledge, pp. 173-99.

Cuffaro, Harriet. 1995. Experimenting with the World: John Dewey and the Early Childhood Classroom. New York: Teachers College Press.

Dyson, Anne Haas, and Celia Genishi, eds. 1994. The Need for Story: Cultural Diversity in Classrooms and Community. Urbana: National Council for Teachers of English.

Dyson, Anne Haas, and Celia Genishi. 2005. On the Case: Approaches to Language and Literacy Research. New York: Teachers College Press.

Edwards, Carolyn, Lella Gandini, and George Forman, eds. 1998. The Hundred Languages of Children: The Reggio Emilia Approach-Advanced Reflections, 2nd ed. New York: Elsevier Science.

Forcey, Linda Rennie. 1994. Feminist perspectives on moth- ering and peace. Edited by Evelyn Nakano Glenn, Grace Chang and Linda Rennie Forcey. In Mothering: Ideology, Experience, and Agency. New York: Routledge, pp. 355-75.

Foucault, Michel. 1972. The Archaeology of Knowledge. Translated by A. M. Sheridan Smith. New York: Routledge.

Foucault, Michel. 1979. Discipline and Punish: The Birth of the Prison. New York: Vintage Books.

Freire, Paulo. 1985. Reading the world and reading the word: An interview with Paulo Freire. Language Arts 62: 15-21.

Fröebel, Friedrich. 1980. Småbørnspædagogik (the Education of Young Children). Translated by V. Tønsberg. København: Nyt Nordisk Forlag Arnold Busck. First published 1844.

Fröebel, Friedrich. 2005. The Education of Man. Translated by William Nicholas Hailman. Mineola: Dover Publications. First published 1826.

Gallas, Karen. 1994. The Languages of Learning: How Children Talk, Write, Dance, Draw, and Sing Their Understanding of the World. New York: Teachers College Press.

Glenn, Evelyn Nakano, Grace Chang, and Linda Rennie Forcey, eds. 1994. Mothering: Ideology, Experience, and Agency. New York: Routledge.

Goldstein, Lisa S. 1998a. Teaching with Love: A Feminist Approach to Early Childhood Education. New York: Peter Lang.

Goldstein, Lisa S. 1998b. More than Gentle Smiles and Hugs: Applying the Ethic of Care to Early Childhood Education. Journal of Research in Childhood Education 12: 244-61. [CrossRef] 
Gore, Jennifer M. 1995. Foucault's poststructuralism and observational education research: A study of power rela-tions. In After Postmodernism: Education, Politics and Identity. Edited by Richard A. Smith and Philip Wexler. London: Psychology Press, pp. 98-111.

Greene, Maxine. 1973. Teacher as Stranger: Educational Philosophy for the Modern Age. Belmont: Wadsworth Publishing Company.

Grumet, Madeleine. 1988. Bitter Milk: Women and Teaching. Amherst: University of Massachusetts Press.

Henward, Allison Sterling. 2018. Examining discursive formations in early childhood media research: A genealogical analysis. Global Studies of Childhood 8: 225-37. [CrossRef]

Hill, Shirley A. 2002. Teaching and Doing Gender in African American Families. Sex Roles 47: 493-506. [CrossRef] Hoagland, Sarah Lucia. 1990. Some Concerns about Nel Noddings' “Caring”. Hypatia 5: 109-14. [CrossRef]

Jones, Liz, and Jayne Osgood. 2007. Mapping the Fabricated Identity of Childminders: pride and prejudice. Contemporary Issues in Early Childhood 8: 289-300. [CrossRef]

Miller, Janet L. 2005. Sounds of Silence Breaking: Women, Autobiography, Curriculum. New York: Peter Lang.

Montessori, Maria. 1912. The Montessori Method. Cambridge: Robert Bentley, Inc.

Montessori, Maria. 1970. The Child in the Family. Translated by N. R. Cirillo. Chicago: Henry Regnery Company. First published 1956.

Noddings, Nel. 1984. Caring: A Feminist Approach to Ethics and Moral Education. Berkeley: University of California Press.

Osgood, Jayne. 2005. Who cares? The Classed Nature of Childhood. Gender and Education 17: 289-303. [CrossRef] Osgood, Jayne. 2006. Deconstructing Professionalism in Early Childhood Education: Resisting the Regulatory Gaze. Contemporary Issues in Early Childhood 7: 5-14. [CrossRef]

Osgood, Jayne. 2010. Narrative Methods in the Nursery: (re)considering claims to give voice through processes of decision-making. Reconceptializing Educational Research Methodology 1: 14-28. [CrossRef]

Osgood, Jayne. 2012. Narratives from the Nursery: Negotiating Professional Identities in Early Childhood. New York: Routledge.

Pacini-Ketchabaw, Veronica, Fikile Nxumalo, Laurie Kocher, Enid Elliot, and Alejandra Sanchez. 2014. Journeys: Reconceptualizing Early Childhood Practices through Pedagogical Narration. Toronto: University of Toronto Press.

Page, Jools. 2011. “Do Mothers Want Professional Carers to Love Their Babies?". Journal of Early Childhood Research 9: 310-23. [CrossRef]

Page, Jools. 2018. Characterising the principles of professional love in early childhood care and education. International Journal of Early Years Education 26: 125-41. [CrossRef]

Paley, Vivian Gussin. 1984. Boys and Girls: Superheroes in the Doll Corner. Chicago: University of Chicago Press.

Paley, Vivian Gussin. 2009. The Importance of Fantasy, Fairness, and Friendship in Children's Play: An Interview with Vivian Gussin Paley. American Journal of Play 2: 121-38.

Pestalozzi, Johann Heinrich. 1951. The Education of Man. Translated by H. Norden, and R. Norden. New York: Philosophical Library. (Originally published anonymously in 1780 in a series of aphorisms entitled The Evening Hours of a Hermit).

Pinedo-Burns, Heather J. 2015. Puffins, Butterflies, and Clouds in the Preschool: The Importance of Wonder. In Rethinking Readiness in Early Childhood Education. Critical Cultural Studies of Childhood. Edited by J. M. Iorio and W. Parnell. New York: Palgrave Macmillan.

Recchia, Susan, Minsun Shin, and Carolina Snaider. 2018. Where is the love? Developing loving relationships as an essential component of professional infant care. International Journal of Early Years Education 26: 142-58. [CrossRef]

Richardson, Laurel. 2005. "Writing: A Method of Inquiry". In Handbook of Qualitative Research, 3rd ed. Edited by Norman Denzin and Yvonne Lincoln. Thousand Oaks: Sage.

Rinaldi, Carla. 2001. Infant-Toddler Centers and Preschools as Places of Culture. In Making Learning Visible: Children as Individual and Group Learners. Reggio Emilia: Reggio Children.

Roop, Kara, and Allison Sterling Henward. 2020. I am Roha's Emaye: A critical autoethnography of mothering in liminal spaces. Genealogy In pressing. 
Souto-Manning, Mariana, and Jessica Martell. 2016. Reading, Writing, and Talk: Inclusive Teaching Strategies for Diverse Learners, K-2. New York: Teachers College Press.

Yelland, Nicola, and Dana Frantz Bentley, eds. 2018. Found in Translation: Connecting Reconceptualist Thinking with Early Childhood Education Practices. New York: Routledge.

(C) 2020 by the author. Licensee MDPI, Basel, Switzerland. This article is an open access article distributed under the terms and conditions of the Creative Commons Attribution (CC BY) license (http://creativecommons.org/licenses/by/4.0/). 